\title{
Analysis of Selected Seasonality Effects in Market of Rubber Future Contracts Quoted on Tokyo Commodity Exchange
}

\author{
Krzysztof Borowski ${ }^{1}$ \\ ${ }^{1}$ Warsaw School of Economics, Poland \\ Correspondence: Krzysztof Borowski, Warsaw School of Economics, Warsaw 02-591, al. Niepodleglosci 162, \\ Poland. Tel: 485-1027-5217. E-mail: kborowski@upcpoczta.pl
}

Received: June 1, 2015

doi:10.5539/ijef.v7n9p15
Accepted: June 15, 2015

Online Published: August 25, 2015

URL: http://dx.doi.org/10.5539/ijef.v7n9p15

\begin{abstract}
The commodity market has been becoming one of the main popular segments of the financial markets among individual and institutional investors in recent years, due to downward trend on the stock exchanges. Likely to the equity market, the problem of anomalies in the commodities market is becoming an interesting phenomenon, particularly in the segment of the agricultural market. This paper tests the hypothesis of: monthly, daily, the day-of-the week, the first and the second half of monthly effects on the market of rubber futures, quoted in the period from 01.12.1981 to 31.03.2015. Calculations presented in this paper indicate the existence of monthly effect: in May and November, with the use of the average monthly rates of return and in February, March, April, June, July, August, October and December, when the daily average rates of return were implemented. The seasonal effects were also observed in the case of testing the statistical hypothesis for daily averaged rates of returns for different days of the month $\left(15^{\text {th }}\right)$, as well as for the daily average rates of retuarn on various days of the week (Thursday). The seasonal effects were no registered for the daily average rates of return in the first and in the second half of a month.
\end{abstract}

Keywords: market efficiency, commodity market, rubber, calendar anomalies

\section{Introduction}

According to Efficient Market Hypothesis (EMH), introduced by Fama (1970), the security prices fully reflect all available information. This theory has been subjected to many analysis and has become a main source of disagreement between academics and practitioners. The latter tends to reject the EMH while the academics support it. Current definitions of EMH differ from that formulated by Fama (1970). According to them, the efficiency of markets prevents systematic beating the market, usually in a form of above-average risk-adjusted returns. Because of the fact, that stock market anomalies breach the EMH, they are the subject to many empirical research. The problem of the financial markets efficiency, especially of equity markets, has become a main topic of number of scientific works, which has led to a sizable set of publications examining this issue. In many empirical work dedicated to the time series analysis of rates of return and stock prices, statistically significant effects of both types were found, i.e. calendar effects and effects associated with the size of companies. These effects are called "anomalies", because their existence testifies against market efficiency. Discussion of the most common anomalies in the capital markets can be found, among others, in Simson (1988) or Latif et al. (2011).

One of the most common calendar anomalies observed on the financial markets are:

A) Day-of-the-week effect-different distributions of expected rates of return can be observed for different days of the week (Keim \& Stambaugh, 1984). Strong evidence of the day-of-the-week effect has been found by many academics in major markets (Gibbon \& Hess, 1981). The day-of-the-week effect in the US market was also presented, among others, in the works of: Jaffe et al. (1989), French (1980), Lakonishok and Maberly (1990). The evidence for UK market was examined by: Theobald and Price (1984), Jaffe and Westerfield (1985), Board and Sutcliffe (1988), Agrawal and Tandon (1994), Peiro (1994), Mills and Coutts (1995), Dubois and Louvet (1996), Coutts and Hayes (1999). Peiro (1994), Agrawal and Tandon (1994), Dubois and Louvet (1996) and Kramer (1996), Marquering et al. (2006) provided evidence of negative Monday and Tuesday returns for Frankfurt exchange. In works of Solnik and Bousquet (1990), Agarwal and Tandon (1994), there was found an evidence of negative Tuesday rates of return in Paris market, while Condoyanni et al. (1987) and Peiro (1994) demonstrated negative Monday and Tuesday rates or return on the same market and Barone (1990) in Milan. 
Research regarding rates of return on other markets was performed in works of Kato et al. (1990), and also by Sutheebanjard and Premchaiswadi (2010). On the Polish market, findings regarding the day-of-the-week effect were conducted among others by: Buczek (2005, pp. 51-55) and Szyszka (2007, pp. 141-146).

B) Monthly effect-achieving by portfolio replicating the specified stock index, different returns in each month. The most popular monthly effect is called "January effect", i.e. the tendency to observe higher average rate of return of stock market indices in the first month of the year (Haug \& Hirschey, 2006). For the first time, this effect was observed by Keim (1983), who noted that the average rate of return on stocks with small capitalization is the highest in January. In case of large and mid-capitalization companies, the effect was not so perceptible. Although January was the best single month in UK, the period from December to April consisted of months, which on average produced positive returns (Rozeff \& Kinney 1976, Corhay et al. 1988). Bernstein (1991), taking into consideration the behavior of the US equity market in the period from 1940 to 1989 , observed the interdependence between rates of returns in each month. Keong et al. (2010) concluded that most of the Asian countries exhibit positive rates of return in December except Hong Kong, Japan, Korea and China. Modern researches, e.g. Gu (2003) and Schwert (2002) prove that in the last two decades of the twentieth century, phenomenon of the month-of-the-year effect was much weaker. To the same conclusion came Seow and Wong (1998) on the Singapore market, Gu (2003)-on the USA market and Gu and Simon (2003) on the UK market. This fact would suggest that the discovery and dissemination of the monthly effect in world financial literature contributed to the increase of market efficiency.

C) Other seasonal effects-in the financial literature, the following calendar effects can be found:

\section{1). The weekend effect}

Cross (1973) found that markets tend to raise on Fridays and fall on Mondays. His findings generated a flood of research (Lakonishok \& Levi, 1982; Jaffe \& Westerfield, 1985; Condoyanni et al., 1987; Connolly, 1991, Abraham \& Ikenberry, 1994; Chen \& Signal, 2003). In the literature two ways of computing weekend rates of return are implemented. In the first approach, Friday close and Monday open prices are used, while in the second example Friday close and Monday close prices are employed.

\section{2). The holiday effects}

Markets before holidays or other trading breaks tend to rise. In the US there is a number of studies looking at this issue, e.g., Fields (1934), Ariel (1987 and 1990), Lakonishok and Smith (1988) and Cadsby and Ratner (1992).

\section{3). Within-the-month effect}

Positive rates of returns only occur in the first half of the month (Ariel, 1987; Kim \& Park, 1994).

\section{4). Turn-of-the month effect}

Average rate of return calculated for the last day of the month and for three days of the next month, was higher than the average rate of return calculated for the month, for which the rate of return of only one session, was taken. Lakonishok and Smidt (1988) found that the four days at the turn-of-the-month averaged a cumulative rate of increase of $0,473 \%$ versus $0,0612 \%$ for and average four days. The average monthly increase was $0,349 \%$, i.e., the DJIA went down during non-turn-of-the-month period.

Commodity market is one of the segments of the financial market, characterized by high heterogeneity of assets compared to the stock or bond markets (Johnson \& Soenen, 1997). It is often perceived as a separate asset class, which in turn leads to low correlation of commodity market rates of return in comparison to the returns on the stock or bonds markets. The consequence of this fact is the possibility of constructing more diversified investment portfolio compared to a portfolio solely consisting of shares or bonds. Another factor in favor of investing in the commodity market is the ability to protect the investment portfolio from the negative effects of inflation. This type of investor preferences in building an investment portfolio are clearly visible in the period of increased inflation (Gorska \& Krawiec, 2013). Another factor encouraging investors to carry out investments in the commodity market can be a threat of currency devaluation or the outbreak of armed conflict.

In the world literature, in contrast to the stock market, relatively little attention has been dedicated to the occurrence of the seasonality effects on the agricultural commodity market. This fact was one of the reasons encouraging the author to undertake empirical studies.

The aim of this article is to examine the prevalence of selected seasonality effects on the market of rubber future contract. The prices for rubber futures are expressed in Yen per kilogram and the contract unit is equal to 5000 kilograms. Natural rubber futures are listed on a number of exchanges all over the world, e.g.: The RSS3 (Ribbed Smokde Sheets no. 3) natural rubber-on the Osaka Mercantile Exchange (OME), the Tokyo Commodity 
Exchange (TOCOM), The Singapore Commodity Exchange (SICOM), The Agricultural Futres Exchange of Thailand (AFE) and the Shanghai Futures Exchange (SEF).

Analysis of the seasonality effects will apply to monthly returns (average monthly returns and average daily returns in each of analyzed months), to returns over various days of the week, over various days of a month, and as well as to average daily rates of return in the first (days from the $1^{\text {st }}$ to the $15^{\text {th }}$ ) and in the second half of month (from $16^{\text {th }}$ to the end of the month). Statistical tests were conducted for rubber futures on the basis of Reuters prices for the period from 01.12.1981 to 31.03.2015.

\subsection{Relevant Literture}

In the scientific literature a statement can be found that the stock market is somehow predestined to record number of anomalies, whereas the foreign exchange is the most effective of all the markets (Froot \& Thaler 1990). It is worth noting that the number of scientific papers dedicated to commodity market efficiency is lower than those relating to the stock market. Numerous research has examined the price efficiency of agricultural markets. However, many of the studies differ with respect to the analyzed commodity, the covered time period and implemented method of analysis, and the type of data employed in the research (Garcia et al., 1988).

Tests of price market efficiency in a weak form were conducted among others by Bigman et al. (1983), Kofi (1972), Leath and Garcia (1983), Springs (1981) and Tomek and Gray (1970). All of these studies focused on the following agricultural commodities: wheat, corn, soybeans (Bigman et al., 1983), wheat, corn, soybeans, cocoa, coffee (Kofi, 1972), corn (Leath \& Garcia, 1983 ), corn (Springs, 1981), corn, soybeans and potatoes (Tomek \& Gray, 1970). In turn, test of price market efficiency in a semi-strong form were performed by Canarella and Pollard (1985), Just and Rausser (1975), Rausser and Carter (1983) and regarded markets of: wheat, corn, soybeans, soybean oil (the two first papers) and markets of soybean and soybean oil (the third paper).

The price inefficiency of some agriculture commodity markets was proved by (Garcia et al., 1988):

1) Bigman et al. (1983) - wheat, corn and soybeans,

2) Bigman and Goldfarb (1985) - wheat, corn, soybeans,

3) Brinegar (1970) - wheat, corn, rye,

4) Helms et al. (1984) - soybeans, soybean oil,

5) Hunt (1974) - wool,

6) Martel and Helms (1978) - wheat, corn, oats, soybeans, soybean oil,

7) Stevenson and Bear (1970) - cottonseed oil and soybeans.

There are, however, works proving thesis of the effectiveness of selected commodity market segments:

8) Labys and Granger (1970) - corn, oat, rye, wheat, lard,

9) Larson (1960) - corn.

The third group of scientific works prove thesis of the mixed nature of the effectiveness of different types of commodity markets:

10) Cargil and Rausser (1972) - corn, oat, rye, soybeans, wheat,

11) Cargil and Rausser (1975) - corn, oat, rye, soybeans, wheat,

12) Gordon (1985) - wheat, corn, rough rice, soybeans, cotton, orange juice, soybean oil,

13) Labys and Granger (1970) - cottonseed oil, corn, cocoa, lard, soybeans, soybean oil, cotton, rye, oat, wheat, rubber,

14) Martel and Phillippatos (1974) - wheat and soybeans,

15) Smidt (1965) - rye and soybeans.

On the basis of above mentioned research, one may formulate the hypothesis that the markets were relatively efficient prior to 1973. Due to the increasing turbulence in the 1970s, the market inefficiency was observed in the period from 1973 to 1979 . The period from 1979 to 1987 was hypothesized to be more efficient than the period from 1973 through 1979 (Garcia et al., 1988). Fortenberry and Zapata (1993) evaluated the relationship of the North Carolina corn and soybean markets with respect to CBOT-no strong evidence was found to reject the efficiency hypothesis. Aulton et al. (1997) investigated the efficiency of agricultural commodities in UK markets. They found wheat market as efficient. Sabuhoro and Lare (1997) demonstrated with the use of cocoa and coffee futures prices, that there was no evidence to reject the null hypothesis concerning the effectiveness of both 
markets. Result indicated by Mckenzie and Holt (1998), on the basis of future and spot prices of some agricultural commodities in the period of 1966-1995, proved that corn and soybean futures markets are both efficient and unbiased in the long-run, but short-run inefficiencies were found to exist in each market.

Wang and Ke (2005) studied wheat and soybean futures markets in China. The results suggest that future market of wheat was inefficient, which might be caused by overspeculation and government intervention on this market. Lokare (2007) found an evidence concerning sugar and cotton markets in India, but Sahoo and Kumar (2009) concluded that the commodity futures markets of soybean oil was efficient in the same country. Ali and Gupta (2011) examined the efficiency of the futures markets of twelve agricultural commodities quoted at NCDEX with the use of Johansen's cointegration analysis. They proved that there was a long-term relationship between futures and spot prices for all of the selected commodities except wheat and rice. Sehgal et al. (2012), during the analysis of ten agricultural prices in the period of June 2003-March 2011 quoted on NCDEX, observed that all commodity markets were efficient except one (turmeric).

Zunino et al. (2011) applied information theory methods to the commodity markets and ranked them finding that silver, copper and cotton were the most efficient commodities in the analyzed period. Kim et al. (2011b) with the use of the random matrix theory and network analysis, found that stock and commodity markets were well decoupled except oil and gold, showing signs of inefficiency. The analysis of Korean agricultural market with the application of detrended fluctuation analysis proved its inefficiency (Kim et al., 2011a). Lee et al. (2013) found that returns in October for corn, April for soybeans and August for wheat futures dominate returns of other months.

Kristoufek and Vosvrda (2013) introduced the Efficiency Index to rank the commodity according to their efficiency. Authors analyzing daily futures prices of 25 commodities, registered the strongest anti-persistence concerning cocoa, oats and orange juice. There were sugar, copper, palladium and platinum among commodities with a signs of persistence. On the other hand, cotton and natural gas were classified as the closest to the efficient market value. With the use of Efficiency Index calculated for all of analyzed commodities, the most efficient of the commodities turned out to be heating oil, followed by WTI crude oil. Cotton, wheat and coffee came after these with the smaller level of efficiency. Kellard et al. (1999) analyzed the efficiency of several commodities traded in different markets, including soybeans on the CBOT, finding a long-run equilibrium relationship but a short-run inefficiency for most of the markets.

Ovararin and Meade (2010) with the use of GARCH model proved that day-of-the-week seasonality effect was observed for rubber, rough rice and white sugar. For rubber, the day-of-the-week reached the peak and the bottom on Monday and Wednesday, respectively. Ciner (2002) examining the relationship between volume and price in rubber future market in Tokyo, proved with the use of linear Ganger causality test, that volume do not explain the expected rates of return.

In summary, there has not been consensus about the efficiency of agricultural commodities. One reason for the heterogeneous results are the different test setups and the second a single-market perspective (Otto, 2011).

\section{Methods}

The adapted methodology can be divided into two parts:

1) Testing the null hypothesis regarding equality of variances of rates of return in two populations,

2) Testing the null hypothesis regarding equality of averages rates of return in two populations.

\subsection{Testing the Null Hypothesis Regarding Equality of Variances of Rates of Return in Two Populations}

The null and alternative hypothesis can be formulated as follows:

$$
\begin{aligned}
& { }_{0}^{F} H: S_{1}^{2}=S_{2}^{2} \\
& { }_{1}^{F} H: S_{1}^{2} \neq S_{2}^{2}
\end{aligned}
$$

where:

$S_{1}^{2}$ - variance of rates of return in the first population,

$S_{2}^{2}$ - variance of rates of return in the second population.

As the last part of the calculation will be carried out using the F-statistics (so called Fisher-Snadecor statistics)

for equality of variances of two population rates of return, where $F=\frac{S_{i}^{2}}{S_{j}^{2}}$, with the condition that: $S_{i}^{2}>S_{j}^{2}$ and the degrees of freedom are equal: 
$n_{i}$ - for variance in the numerator of $F$,

$n_{j}$ - for variance in the denominator of $F$.

If F-test (computed for $\alpha=0,05$ ) is lower than F-statistics, e.g. the ratio F-test to F-statistics is lower than 1 , there is no reason to reject the null hypothesis.

\subsection{Testing the Null Hypothesis Regarding Equality of Average Rates of Returns in Two Populations}

According to the adopted methodology, the survey covers two populations of returns, characterized by normal distributions. On the basis of two independent populations of rate of returns, which sizes are equal $n_{1}$ and $n_{2}$, respectively, the hypotheses $\mathrm{H}_{0}$ and $\mathrm{H}_{1}$ should be tested with the use of statistics $z$ (Osinska, 2006, pp. 43-44):

$$
\mathrm{z}=\frac{\overline{\mathrm{r}_{1}}-\overline{\mathrm{r}_{2}}}{\sqrt{\left(\frac{\mathrm{s}_{1}^{2}}{\mathrm{n}_{1}}+\frac{\mathrm{s}_{2}^{2}}{\mathrm{n}_{2}}\right)}}
$$

where:

$\overline{r_{1}}$-average rate of return in the first population,

$\overline{r_{2}}$-average rate of return in the second population,

The Formula 2 can be used in the case of normally distributed populations, when the populations variances are unknown but assumed equal. The number of degrees of freedom is equal to: $d f(1)=n_{1}+n_{2}-2$.

When the populations variances are unequal, the number of degrees should be modified according to the following formula (Defusco et al., 2001, p. 335):

$$
d f(2)=\frac{\left(\frac{s_{1}^{2}}{n_{1}}+\frac{s_{2}^{2}}{n_{2}}\right)^{2}}{\frac{\left(s_{1}^{2} / n_{1}\right)^{2}}{n_{1}}+\frac{\left(s_{2}^{2} / n_{2}\right)^{2}}{n_{2}}}
$$

In the case of two populations, both with equal or unequal variances, the null hypothesis $H_{0}$ and alternative hypothesis $H_{l}$ regarding equality of rates of return in two populations, can be formulated as follows:

In particular:

$$
\begin{aligned}
& H_{0}: E\left(r_{1}\right)=E\left(r_{2}\right) \\
& H_{1}: E\left(r_{1}\right) \neq E\left(r_{2}\right)
\end{aligned}
$$

1) For the analysis of the monthly rates of return, if $\overline{r_{1}}$ is the monthly average rate of return in month $X$ (the first population), then $\overline{r_{2}}$ is the monthly average rate of return in all other months, except month $X$ (the second population).

2) For the analysis of the daily rates of return, if $\overline{r_{1}}$ is the daily average rate of return in month $X$ (the first population), then $\overline{r_{2}}$ is the daily average rate of return in all other months, except month $X$ (the second population).

3) For the analysis of the daily rates of return for individual days of the week, if $\overline{r_{1}}$ is the daily average rate of return on day $Y$ (the first population), then $\overline{r_{2}}$ is the daily average rate of return in all other days, except day $Y$ (the second population).

4) For the analysis of the rates of return for individual days of month, if $\overline{r_{1}}$ is the daily average rate of return on day $Y$ (the first population), then $\overline{r_{2}}$ is the daily average rate of return in all other days, except day $Y$ (the second population).

5) For the analysis within-the-month effect, if $\overline{r_{1}}$ is the average rate of return in the first half of the analyzed months (days from the $1^{\text {st }}$ to the $15^{\text {th }}$-the first population), then $\overline{r_{2}}$ is the average rate of return in the second half (days from $16^{\text {th }}$ to the end of the analyzed month-the second population).

In all analyzed cases, the p-values will be calculated with the assumption that the populations variances are unknown, but:

1) population variances are assumed equal-p-value(1),

2) population variances are assumed unequal-p-value(2).

In the case, when there is no reason to reject the null hypothesis about equality of variances of two observed returns, the p-value(1) should be compared with the critical value 0,05 ; otherwise the p-value(2) will be used. If 
the p-value (p-value(1) or p-value(2)) is less than or equal to 0,05 ; then the hypothesis $H_{0}$ is rejected in favor of the hypothesis $H_{l}$. Otherwise, there is no reason to reject hypothesis $H_{0}$. In the part 3 of the article, the p-value listed in the tables are equal to p-value(1) or p-value(2) depending on the result of testing the null hypothesis, concerning the equality of variance in the two populations of rates of returns.

\section{Results}

\subsection{The Analysis of the Monthly Effect}

The prices of rubber futures in the period from 01.01.1981 to 31.03.2015 are presented in Figure 1.

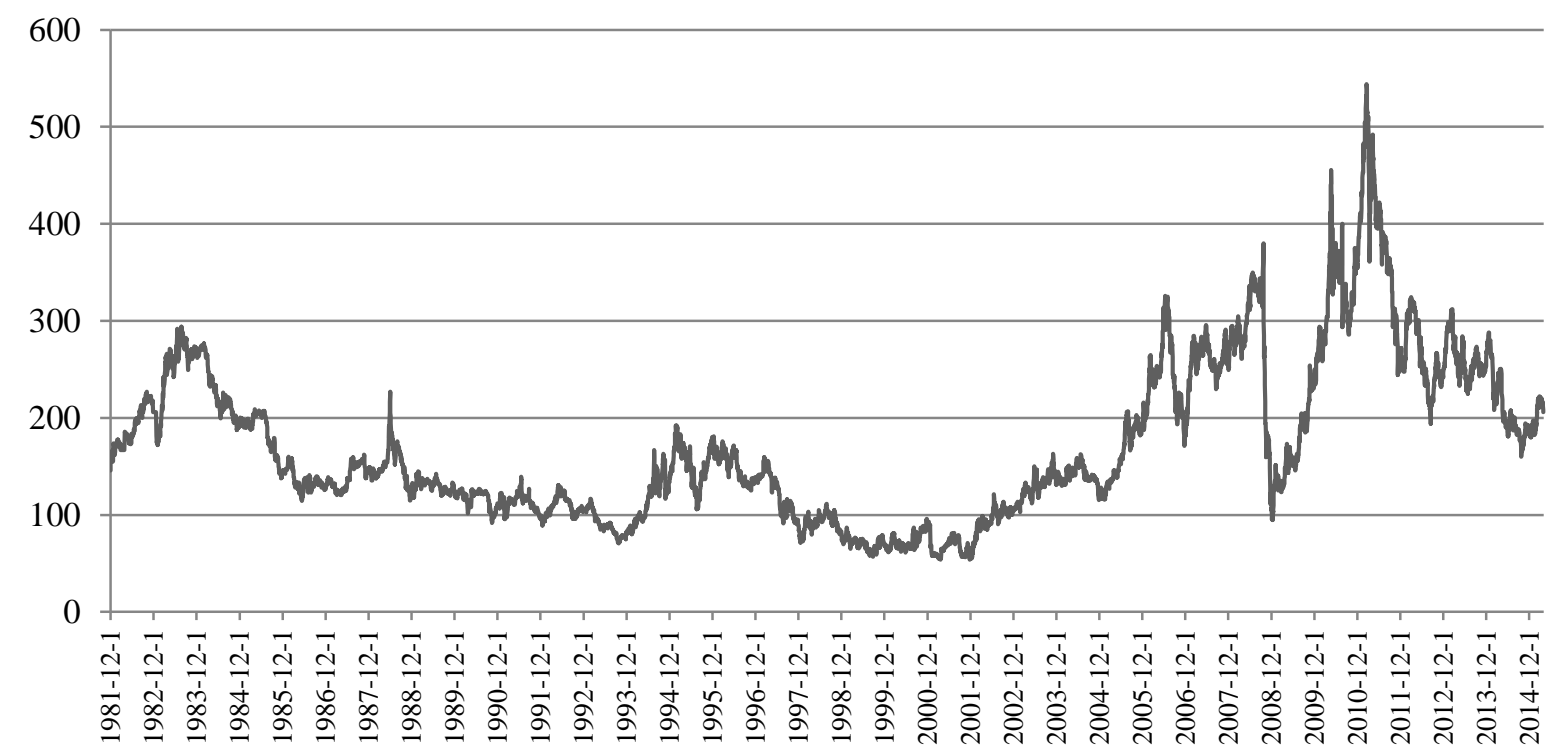

Figure 1. The daily rubber futures prices in Yen in the period from 01.01.1981 to 31.03.2015

Source: own calculations.

The monthly average rates of return of rubber futures are visible in Table 1. The highest monthly rate of return equal to $4,57 \%$ was observed in May, and the lowest one $(-2,85 \%)$ in November. The monthly average rates of return, higher than $2 \%$ were registered 3 times, e.g. in May (4,57\%), January $(4,21 \%)$, and December $(3,75 \%)$. The monthly average rates of return lower than minus $1 \%$ occurred 4 times in analyzed period: in November $(-2,85 \%)$, September (-1,86\%), June (-1,82\%) and August (-1,19\%).

Table 1 . The number and percentage of positive and negative monthly returns on the markets of rubber futures in the analyzed period

\begin{tabular}{|c|c|c|c|c|c|c|c|c|c|c|c|c|}
\hline & January & February & March & April & May & June & July & August & September & October & November & December \\
\hline $\begin{array}{l}\text { Monthly average rate of } \\
\text { return in } \%\end{array}$ & 4,2126 & 1,4804 & 0,9745 & $-0,5571$ & 4,5677 & $-1,8173$ & $-0,2541$ & $-1,1869$ & $-1,8618$ & 0,2486 & $-2,8525$ & 3,7479 \\
\hline $\begin{array}{l}\text { Percentage of months with } \\
\text { positive rates of return }\end{array}$ & $57,58 \%$ & $51,52 \%$ & $51,52 \%$ & $45,45 \%$ & $57,58 \%$ & $48,48 \%$ & $43,75 \%$ & $39,39 \%$ & $39,39 \%$ & $48,48 \%$ & $33,33 \%$ & $69,70 \%$ \\
\hline $\begin{array}{l}\text { Percentage of months with } \\
\text { negative rates of return }\end{array}$ & $42,42 \%$ & $48,48 \%$ & $48,48 \%$ & $54,55 \%$ & $42,42 \%$ & $51,52 \%$ & $56,25 \%$ & $60,61 \%$ & $60,61 \%$ & $51,52 \%$ & $66,67 \%$ & $30,30 \%$ \\
\hline
\end{tabular}

Source: own calculations.

The number and percentage of positive and negative monthly returns on the rubber futures market for each month, are presented in Table 1 and on the Figure 2 . In the analyzed period, the positive monthly returns, were the most frequently observed in December-in $69,70 \%$ of all observations. The second and the third months, in which the positive returns were most frequent were: January and May-57,58\% in both cases. In turn, the months with the highest percentage of negative monthly returns resulted to be: August and September-60,61\% in both 
cases.

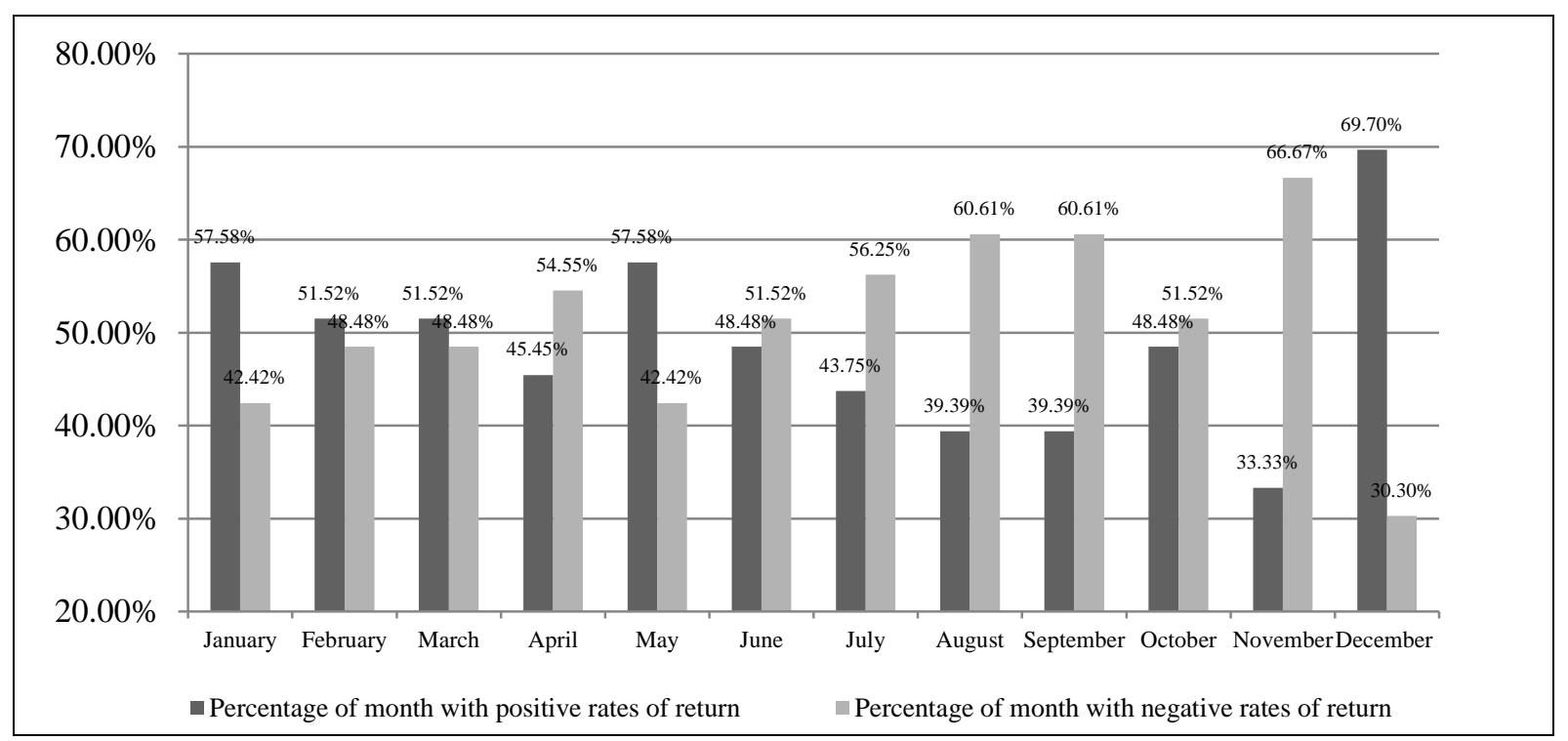

Figure 2. The percentage of monthly positive and negative returns in each month

Source: own calculations.

The outcome obtained in the process of testing statistical hypotheses for the monthly returns on market of rubber futures, are presented in Table 2.

Table 2. The results of testing the null hypothesis for the monthly returns for prices of rubber futures

\begin{tabular}{lcccccccccccc}
\hline & January & February & March & April & May & June & July & August & September & October & November & December \\
\hline p-value & 0,0628 & 0,4746 & 0,7432 & 0,4028 & 0,0222 & 0,1240 & 0,6432 & 0,2611 & 0,0956 & 0,8711 & 0,0149 & 0,0557 \\
F statistics /F-Test & 1,0063 & 1,1091 & 1,1536 & 0,9912 & 0,8221 & 0,6945 & 0,7840 & 0,6857 & 0,8060 & 1,0014 & 0,8786 & 0,7249 \\
\hline
\end{tabular}

Source: own calculations.

The results permit to draw the following conclusions:

1) There was no reason to reject the null hypothesis regarding equality of variances of monthly rates of return in two populations in the following months: April, May, June, July, August, September, November and December. In all other months (e.g. in January, February, March, October) the variances of daily rates of return in two group of populations were different (for $\alpha=0,05$ ). For the first group of months the p-value(1), and for the second group the p-value(2), are valid.

2) In the process of testing the equality of monthly rates of return in two groups of populations, the null hypothesis was rejected in favor of the alternative hypothesis for the following months: May and November. This fact indicates the occurrence of the effect of the month on the analyzed market. In the both cases the p-value(1) was deeply lower than the critical value 0,05 (0,0222 in May and 0,0149 in November) what can be interpreted as a strong monthly effect-with the remark that the November monthly effect was bigger. Regarding all of the remaining months, the null hypothesis was not rejected, which indicates that month of the year effect did not occur. It is worth to mention that p-value(1) calculated for monthly rates of return in December was equal to 0,0557 ; and the p-value(2) in January mounted to 0,0628 . The December p-value(1) stands just a little above the critical value $(0,05)$.

\subsection{The Analysis of the Day-of-the-Week Effect}

Average rates of return for each day of the week on the market of rubber futures are shown in the Table 3 . In the same table the results of testing statistical hypotheses are presented for the daily rates of returns for different days of the week during analyzed period. 
The negative average daily rates of return were observed for the following days of the week: Monday $(-0,0648)$, Tuesday $(-0,0657 \%)$, Wednesday $(-0,0712)$, and positive for: Thursday $(0,0861 \%)$ and Friday $(0,0137 \%)$. The highest average daily rate of return for rubber futures was observed on Thursdays $(0,0861 \%)$, and the lowest on Wednesdays $(-0,0712 \%)$.

Table 3. The results of testing the null hypothesis for the day-of-the week rates of return

\begin{tabular}{lccccc}
\hline & Monday & Tuesday & Wednesday & Thursday & Friday \\
\hline p-value & 0,3941 & 0,3536 & 0,3026 & 0,0252 & 0,5519 \\
F statistics /F-Test & 1,0147 & 1,0768 & 1,0430 & 1,1294 & 1,2845 \\
\hline
\end{tabular}

Source: own calculations.

The results of testing null hypothesis permit to draw the following conclusion.

1) For all days of the week the null hypothesis regarding equality of variances of daily average rates of return in two populations was rejected (for $\alpha=0,05$ ).

2) There was no reason to reject the null hypothesis regarding equality of two average rates of return for all day of the week except Thursday. The Thursday p-value(2) amounted to 0,0252. The p-values(2) calculated of all others days of the week were higher than the 0,3 . The highest p-value(2) vas observed for Friday sessions.

Information regarding number and frequency of positive and negative rates of return, computed for each day of the week, are included in Table 4.

Table 4. The number and percentage of positive and negative daily rates of return

\begin{tabular}{lccccc}
\hline & Monday & Tuesday & Wednesday & Thursday & Friday \\
\hline Percentage of sessions with positive rates of return & $49,59 \%$ & $50,09 \%$ & $52,10 \%$ & $53,46 \%$ & $51,66 \%$ \\
Percentage of sessions with negative rates of return & $50,41 \%$ & $49,91 \%$ & $47,90 \%$ & $46,54 \%$ & $48,34 \%$ \\
\hline
\end{tabular}

Source: own calculations.

The rubber futures market experienced positive daily returns mostly on Thursdays $(53,46 \%)$, followed by $52,10 \%$ on Wednesdays and by $51,66 \%$ on Fridays. The negative daily rates of return were reported more often on Mondays $(50,41 \%)$ and Tuesdays $(49,91 \%)$-see Figure 3.

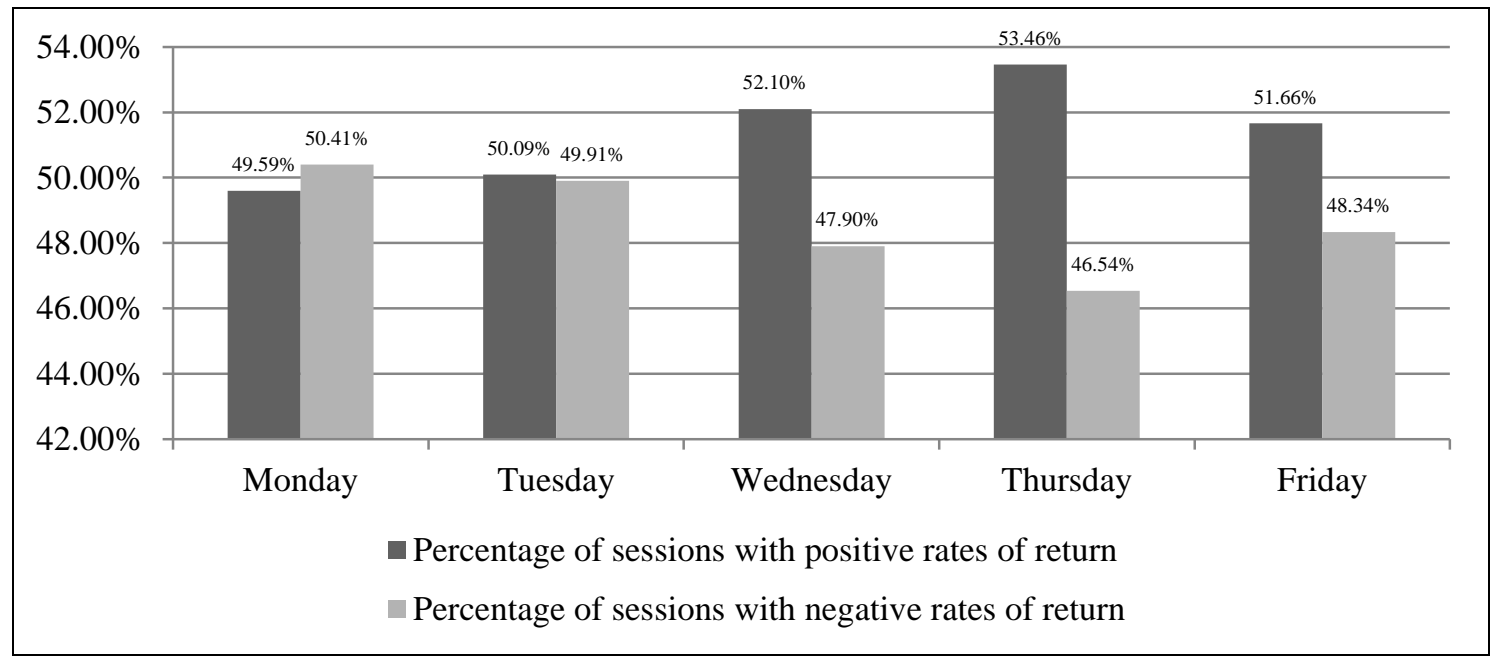

Figure 3. The frequency of positive and negative daily returns over various days of the week for rubber futures prices

Source: own calculations. 


\subsection{The Analysis of the Daily Rates of Return in Different Months}

Analysis of the average daily rates of return of rubber futures, calculated for each of the analyzed months, as well as the result of testing the null hypothesis, are shown in the Table 5.

Table 5. The average daily rates of return on the market of rubber futures and results of testing the null hypothesis for the average daily rates of return in each month

\begin{tabular}{lcccccccccccc}
\hline & January & February & March & April & May & June & July & August & September & October & November & December \\
\hline p-value & 0,0465 & 0,4793 & 0,7423 & 0,5761 & 0,0180 & 0,1466 & 0,5360 & 0,3150 & 0,1539 & 0,7190 & 0,0391 & 0,0976 \\
$\begin{array}{l}\text { F statistics } \\
\text { /F-Test }\end{array}$ & 0,9984 & 1,1632 & 1,1988 & 1,2814 & 0,9165 & 1,0993 & 1,2994 & 1,0614 & 0,9143 & 1,1105 & 0,9520 & 1,2831 \\
\hline
\end{tabular}

Source: own calculations.

The highest average daily rate of return for rubber futures was observed in May $(0,1817 \%)$, and the lowest in November $(-0,1955 \%)$. The second highest and the second lowest average daily rates of return were registered in January $(0,1575 \%)$ and in September $(-0,1449 \%)$, respectively.

The results obtained during testing the null hypothesis permit to formulate the following conclusions:

1) The null hypothesis regarding equality of variances of daily rates of return in two populations was rejected for the following months: February, March, April, June, July, August, October and December.

2) The null hypothesis regarding equality of daily average rates of return in two populations, was rejected in favor of the alternative hypothesis for the following months: January, May and November. This fact indicates the occurrence of the month effect on the analyzed market.

3) The January p-value(1) was slightly lower than the critical value $(0,05)$ and equal to 0,0465 , what can be interpreted as a weak inefficiency effect in comparison to the other two months, for which the p-value(1) mounted to 0,0180 (May) and 0,0391 (November).

4) For all other analyzed months (e.g. February, March, May, June, July, August, September, October and December) there was no reason to reject the null hypothesis referred to equality of average returns in two group of populations.

Information regarding number and frequency of positive and negative rates of return, computed for each day of the week, are included in Table 6.

Table 6. The number and percentage of positive and negative daily rates of returns in each of analyzed months

\begin{tabular}{|c|c|c|c|c|c|c|c|c|c|c|c|c|}
\hline & January & February & March & April & May & June & July & August & September & October & Nowember & December \\
\hline $\begin{array}{l}\text { Percentage of sessions with } \\
\text { positive rates of return }\end{array}$ & $54,73 \%$ & $51,89 \%$ & $52,06 \%$ & $50,08 \%$ & $56,60 \%$ & $49,34 \%$ & $48,43 \%$ & $50,21 \%$ & $49,84 \%$ & $50,74 \%$ & $48,33 \%$ & $54,84 \%$ \\
\hline $\begin{array}{l}\text { Percentage of sessions with } \\
\text { negative rates of return }\end{array}$ & $45,27 \%$ & $48,11 \%$ & $47,94 \%$ & $49,92 \%$ & $43,40 \%$ & $50,66 \%$ & $51,57 \%$ & $49,79 \%$ & $50,16 \%$ & $49,26 \%$ & $51,67 \%$ & $45,16 \%$ \\
\hline
\end{tabular}

Source: own calculations.

On the rubber futures market, the frequency of positive daily returns, higher than $50 \%$ was observed in eight months, and was the highest in May $(56,60 \%)$, and then in December $(54,84 \%)$ and in January $(54,73 \%)$-see Figure 4 . The negative daily rates of return were reported more often in November $(51,67 \%)$, July $(51,57 \%)$ and June $(50,66 \%)$. For three of these six months (January, May and November), the tested null hypothesis regarding equality of average rates of return in two populations, was rejected. 


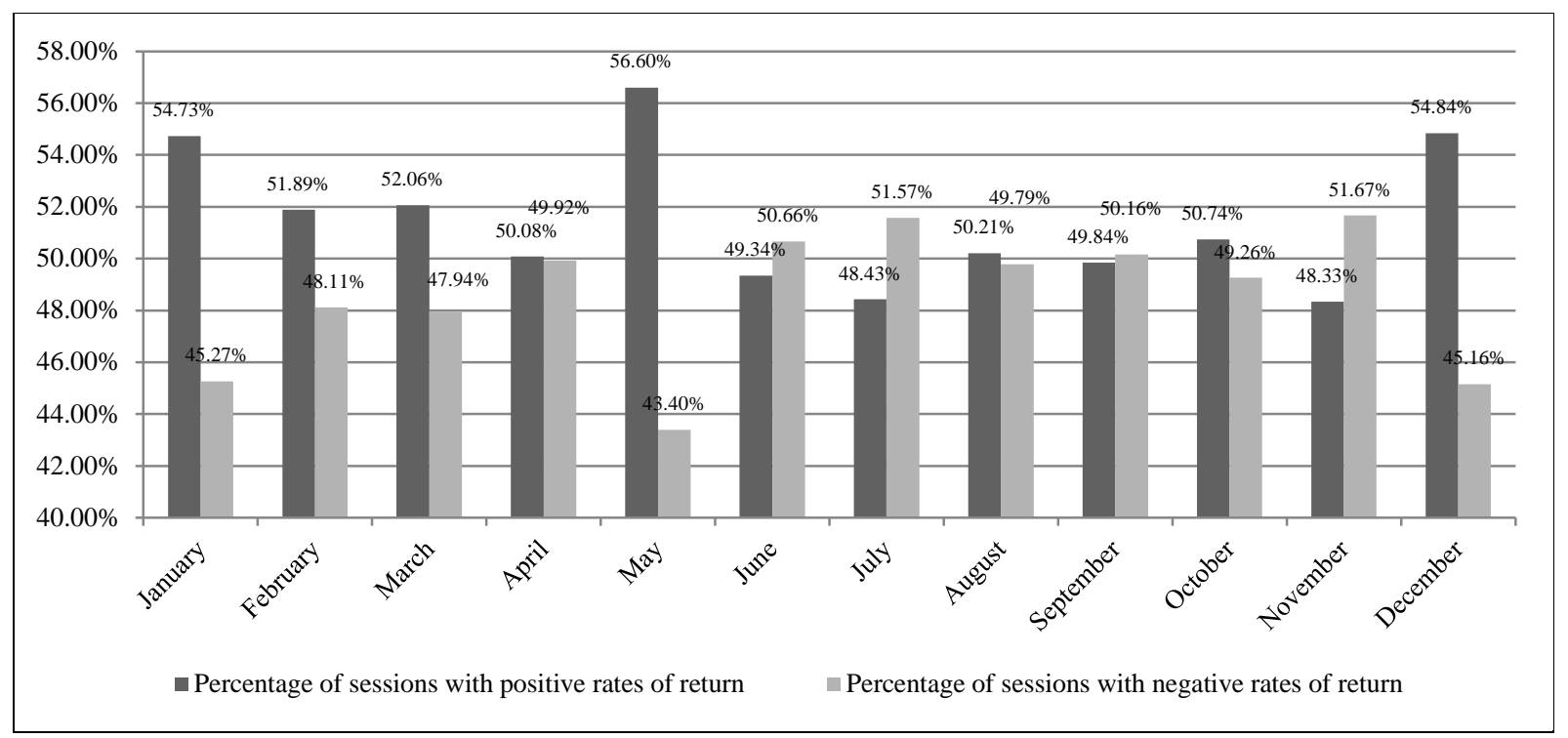

Figure 4. Percentage of positive and negative daily rates of returns in each of analyzed months

Source: own calculations.

\subsection{The Analysis of the Average Daily Rates of Return in Different Days of Month}

Analysis of the average daily rates of return of rubber futures, calculated for each day of the analyzed months, as well as the result of testing the null hypothesis, are shown in the Table 7 . The positive average daily rates of return were observed in 14 out of all 31 days of month, e.g. in. $45,16 \%$ cases. The highest positive value equal $0,2571 \%$ was registered in the $23^{\text {th }}$, and the lowest $(-0,3256 \%)$ in the $15^{\text {th }}$ day of each analyzed months.

The results obtained during testing the null hypothesis allow to formulate the following conclusions:

1) There was no reason to reject the null hypothesis regarding equality of variances of daily rates of return in two populations, for the following six days of month: the $15^{\text {th }}, 19^{\text {th }}, 21^{\text {st }}, 22^{\text {nd }}, 23^{\text {th }}$ and $30^{\text {th }}$. In all other cases, the variances in two group of populations were different (for $\alpha=0,05$ ).

2) The null hypothesis regarding equality of the daily average rates of return in two populations, was rejected in favor of the alternative hypothesis only for the $15^{\text {th }}$ day of the month. The p-value(2) calculated for daily rates of return on the session falling on the $10^{\text {th }}$ and $23^{\text {rd }}$ day of the month, was equal 0,0765 and 0,0830 , respectively, e.g. slightly higher than the critical value $(0,05)$. For all other 28 analyzed days of the month, there was no reason to reject the null hypothesis and the calculated p-value(1) and p-value(2) were higher than 0,1 .

The frequency of positive average daily returns, higher than $50 \%$ was observed during 20 days of each month (64,52\% of all sessions in each month), and was the highest on the $3^{\text {st }}$ day of each month $(57,78 \%)$, and then on the $25^{\text {th }}(57,51 \%)$ and on the $17^{\text {th }}(56,51 \%)$-see Table 5 and Figure 6 . The lowest frequency of positive average daily returns were reported on the $15^{\text {th }}(40,56 \%)$ and on the $5^{\text {th }}(43,92 \%)$ day of each month. 


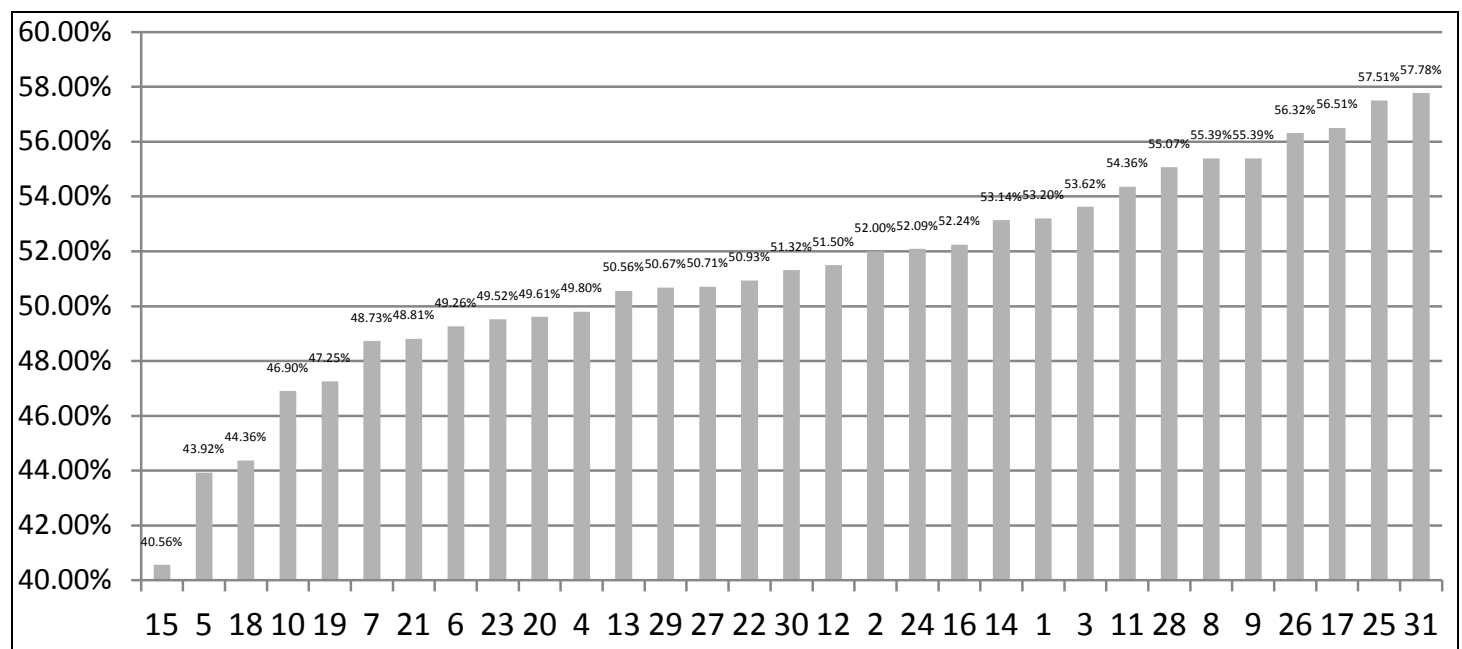

Figure 5. Percentage of positive average daily rates of returns for each of analysed days of the month

Source: own calculations.

\subsection{The Analysis of the Average Daily Rates of Return in the First and the Second Half of Month}

The average daily rate of return in the first and the second half of a month was equal $-0,0529 \%$ and $0,01 \%$, respectively. The F-statistics was equal 1,7456 and the value of F-test mounted to 1,0538. As the F-statistics and F-test ratio was higher than $1(1,6564)$, the null hypothesis, regarding equality of variances of daily rates of return in two populations, was rejected. There was no reason to reject the null hypothesis referring to the equality of average rates of return in two populations. It means that the daily average rates of return in the first half do not differ from the daily average rates of return in the second half of a month (for $\alpha=0,05$ ). The $p$-value(2) calculated in the process of testing the null hypothesis was higher than the critical value $(0,05)$ and mounted to 0,2152 .

The frequency of positive average daily returns in the first half of the month was equal 50,55\%, whilst in the second half was a little bit higher-51,81\%. The frequency of negative average daily returns in the first half of the month mounted to $49,45 \%$, and in the second to $48,19 \%$. Both, in the first and the second half, the frequency of positive daily rates of return was higher than the frequency of daily negative rates of return.

Table 7. The average daily rates of return on the market of rubber futures and results of testing the null hypothesis for the average daily rates of return for the first half of the month (days: 1-15)

\begin{tabular}{lccccccccccccccc}
\hline Day of the month & 1 & 2 & 3 & 4 & 5 & 6 & 7 & 8 & 9 & 10 & 11 & 12 & 13 & 14 & 15 \\
\hline Average r1 in \% & $0,0608 \%$ & $-0,0843 \%$ & $0,1319 \%$ & $0,0736 \%$ & $-0,2090 \%$ & $-0,0201 \%$ & $0,0193 \%$ & $-0,0532 \%$ & $0,0317 \%$ & $-0,2364 \%$ & $0,1269 \%$ & $-0,0466 \%$ & $-0,1248 \%$ & $-0,0987 \%$ & $-0,3256 \%$ \\
p-value & 0,4608 & 0,5943 & 0,1964 & 0,4552 & 0,1130 & 0,9959 & 0,7402 & 0,7817 & 0,6420 & 0,0765 & 0,2290 & 0,8199 & 0,3242 & 0,5066 & 0,0225 \\
\hline
\end{tabular}

Source: own calculations.

Table 8. The average daily rates of return on the market of rubber futures and results of testing the null hypothesis for the average daily rates of return for the second half of the month (days: 16-31)

\begin{tabular}{lccccccccccccccccc}
\hline Day of the month & 16 & 17 & 18 & 19 & 20 & 21 & 22 & 23 & 24 & 25 & 26 & 27 & 28 & 29 & 30 & 31 \\
\hline Average $\mathrm{r}_{1}(\%)$ & $0,0318 \%$ & $0,0922 \%$ & $-0,1106 \%$ & $-0,1418 \%$ & $-0,1625 \%$ & $-0,0803 \%$ & $0,1032 \%$ & $0,2571 \%$ & $-0,0724 \%$ & $0,2159 \%$ & $0,1625 \%$ & $-0,2904 \%$ & $0,1668 \%$ & $-0,0572 \%$ & $0,1215 \%$ & $-0,0643$ \\
p-value & 0,6633 & 0,3248 & 0,4084 & 0,3659 & 0,3621 & 0,6578 & 0,3457 & 0,0830 & 0,7268 & 0,2646 & 0,3625 & 0,2042 & 0,2245 & 0,7720 & 0,3006 & 0,7941 \\
\hline
\end{tabular}

Source: own calculations.

Table 9. The number and percentage of positive and negative daily average rates of returns for each of analyzed days of the month (for days: 1-15)

\begin{tabular}{|c|c|c|c|c|c|c|c|c|c|c|c|c|c|c|c|}
\hline Day of the month & 1 & 2 & 3 & 4 & 5 & 6 & 7 & 8 & 9 & 10 & 11 & 12 & 13 & 14 & 15 \\
\hline Percentage of sessions with positive rates of return & \multicolumn{15}{|c|}{$53,20 \% 52,00 \% 53,62 \% 49,80 \% 43,92 \% 49,26 \% 48,73 \% 55,39 \% 55,39 \% 46,90 \% 54,36 \% 51,50 \% 50,56 \% 53,14 \% 40,56 \%$} \\
\hline Percentage of sessions with negative rates of return & \multicolumn{15}{|c|}{$46,80 \% 48,00 \% 46,38 \% 50,20 \% 56,08 \% 50,74 \% 51,27 \% 44,61 \% 44,61 \% 53,10 \% 45,64 \% 48,50 \% 49,44 \% 46,86 \% 59,44 \%$} \\
\hline
\end{tabular}


Table 10. The number and percentage of positive and negative daily average rates of returns for each of analyzed days of the month (for days: 16-31)

\begin{tabular}{lllllllllllllllll}
\hline Day of the month & 16 & 17 & 18 & 19 & 20 & 21 & 22 & 23 & 24 & 25 & 26 & 27 & 28 & 29 & 30 & 31
\end{tabular}

Percentage of sessions with positive rates of return $52,24 \% 56,51 \% 44,36 \% 47,25 \% 49,61 \% 48,81 \% 50,93 \% 49,52 \% 52,09 \% 57,51 \% 56,32 \% 50,71 \% 55,07 \% 50,67 \% 51,32 \% 57,78 \%$ Percentage of sessions with negative rates of return $47,76 \% 43,49 \% 55,64 \% 52,75 \% 50,39 \% 51,19 \% 49,07 \% 50,48 \% 47,91 \% 42,49 \% 43,68 \% 49,29 \% 44,93 \% 49,33 \% 48,68 \% 42,22 \%$

Source: own calculations.

\section{Discussion}

In recent years, there has been observed an increased interest in the commodity market, including agricultural commodities, from both institutional and individual investors. Investment strategies implemented in the commodity market by its participants, heavily resemble those of the stock and currency markets. However it should be mentioned that particular characteristics are assigned to the agricultural commodity market such as stock level or marginal unit cost. It is also important to note that, despite the physical diversity, this asset class is often characterized by a high degree of price correlation (Fabozzi et al., 2008).

The aim of this study was to determine the prevalence of selected effects of seasonality on the market of rubber futures. Analysis of the effects of seasonality included an examination of monthly returns, daily returns over various days of the week, average daily rates of return in different days of a month and average daily rates of return in the first and the second half of a month. The main limitation of this research is the assumption of normal distribution of return rates of analyzed commodities as well as the use of price data gained from Bloomberg data source.

Calculations presented in this paper indicate the existence of monthly effect: in May and November with the use of the average monthly rates of return and in February, March, April, June, July, August, October and December, when the daily average rates of return were implemented. The seasonal effects were also observed in case of testing the statistical hypothesis for daily averaged rates of returns for different days of the month $\left(15^{\text {th }}\right)$, as well as for the daily average rates of return on various days of the week (Thursday). The seasonal effects were no registered for the daily average rates of return in the first and in the second half of a month.

The results obtained in this paper, in the case of average daily returns in some part deny outcomes received by Ovararin and Meade (2010). In the analyzed period the average daily rates of return were negative both on Monday and Wednesday sessions. The highest average daily rate of return were registered on Thursday, while according to Ovararin and Meade (2010), the higher daily average rate of return characterized Monday sessions. However, the lowest average daily rate of return recorded in this paper on Wednesday session confirms the results of Ovararin and Meade (2010), who claimed that the bottom of the rubber market cycle falls on Wednesday sessions.

Further research on the occurrence of calendar anomalies in the agricultural market should include the following assets: oat, rye and barley.

\section{References}

Abraham, A., \& Ikenberry, D. (1994). Individual investors and the Weekend Effect. Journal of Financial and Quantitative Analysis, 2, 263-277. http://dx.doi.org/10.2307/2331225

Agrawal, A., \& Tandon, K. (1994). Anomalies or illusions? Evidence from stock markets in eighteen countries. Journal of International Money and Finance, 13, 83-106. http://dx.doi.org/10.1016/0261-5606(94)90026-4

Ali, J., \& Gupta, K. (2011). Efficiency in agricultural commodity futures markets in India: Evidence from cointegration and causality tests. Agricultural Finance Review, 71, 162-178. http://dx.doi.org/10.1108/00021461111152555

Ariel, R. (1987). A monthly effect in stock returns. Journal of Financial Economics, 17, 161-174. http://dx.doi.org/10.1016/0304-405X(87)90066-3

Ariel, R. (1990). High stock returns before holidays: Existence and evidence on possible causes. Journal Finance, 45, 1611-1626. http://dx.doi.org/10.1111/j.1540-6261.1990.tb03731.x

Aulton, A., Ennew, C., \& Rayner, A. (1997). Efficiency tests of futures markets for UK agricultural commodities. Journal of Agricultural Economics, 48, 408-423. http://dx.doi.org/10.1111/j.1477-9552.1997.tb01162.x

Barone, E. (1990). The Italian stock market: Efficiency and calendar anomalies. Journal of Banking and Finance, 14, 493-510. http://dx.doi.org/10.2139/ssrn.512503 
Bernsten, J. (1991). Cycles of profit. New York, NY: Harpercolins.

Bigman, D., \& Goldfarb, D. (1985). Efficiency and efficient trading rules for food and feed grains in the world commodity markets: The Israeli experience. Journal of Futures Markets, 5, 1-10. http://dx.doi.org/10.1002/fut.3990050102

Bigman, D., Goldfarb, D., \& Schechtman, E. (1983). Futures market efficiency and the time content of the information sets. Journal of Futures Markets, 3, 321-334. http://dx.doi.org/10.1002/fut.3990030307

Board, J., \& Sutcliffe, C. (1988). The weekend effect in UK stock market returns. Journal of Business, Finance and Accounting, 15, 199-213. http://dx.doi.org/10.1111/j.1468-5957.1988.tb00130.x

Brinegar, C. (1970). A statistical analysis of speculative price behavior. Food Research Institute Studies, 9, 1-57.

Buczek, S. (2005). Efektywność informacyjna rynków akcji. Teoria a rzeczywistość. Warszawa: Szkoła Główna Handlowa w Warszawie.

Cadsby, C., \& Ratner, M. (1992). Turn-of-month and pre-holiday effects on stock returns: Some international evidence. Journal of Banking and Finance, 16, 497-509. http://dx.doi.org/10.1016/0378-4266(92)90041-W

Canarella, G., \& Pollard, S. (1985). Efficiency of commodity futures: A vector autoregression analysis. Journal of Futures Markets, 5, 57-76. http://dx.doi.org/10.1002/fut.3990050107

Cargill, T., \& Rausser, G. (1972). Time and frequency representations of future prices as a stochastic process. Journal of American Statistical Association, 67, 23-30.

Cargill, T., \& Rausser, G. (1975). Temporal price behavior in commodity futures markets. Journal of Finance, 30, 1043-1053. http://dx.doi.org/10.2307/2326722

Chen, H., \& Singal, V. (2003). Role of speculative short sales in price formation: The case of the weekend effect. Journal of Finance, 58, 685-705. http://dx.doi.org/10.1111/1540-6261.00541

Ciner, C. (2002). Information content of volume: An investigation of Tokyo commodity futures markets. Pacific Basin Finance Journal, 10, 201-215. http://dx.doi.org/10.1016/S0927-538X(01)00037-3

Condoyanni, L., O'Hanlon, J., \& Ward, C. (1987). Day of the week effects on stock returns: International evidence. Journal of Business Finance and Accounting, 14, 159-174. http://dx.doi.org/10.1111/j.1468-5957.1987.tb00536.x

Connolly, R. (1991). A posterior odds analysis of the weekend effect. Journal of Econometrics, 49, 51-104. http://dx.doi.org/10.1016/0304-4076(91)90010-B

Corhay, A., Hawawini, G., \& Michel, P. (1988). Stock market anomalies. Cambridge: Cambridge University Press.

Coutts, J., \& Hayes, P. (1999). The weekend effect, the stock exchange account and the financial times industrial ordinary shares index 1987-1994. Applied Financial Economics, 9, 67http://dx.doi.org/10.1080/096031099332537

Cross, F. (1973). The behavior of stock prices and Fridays and Mondays. Financial Analyst Journal, 29, 67-69. http://dx.doi.org/10.2469/faj.v29.n6.67

Daniel, K., Hirshleifer, D., \& Teoh, S. (2002). Investor psychology in capital markets: Evidence and policy $\begin{array}{llll}\text { implications. Journal of } & \text { Monetary }\end{array}$ http://dx.doi.org/10.1016/S0304-3932(01)00091-5

Defusco, R., McLeavey, D., Pinto, J., \& Runkle, D. (2001). Quantitative methods for investment analysis. Baltimore: United Book Press.

Dubois, M., \& Louvet, P. (1996). The day-of-the-week effect: The international evidence. Journal of Banking and Finance, 20, 1463-1484. http://dx.doi.org/10.1016/0378-4266(95)00054-2

Fortenberry, R., \& Zapata, H. (1993). An examination of cointegration relation between futures and local grain markets. Journal of Futures Markets, 13, 921-932. http://dx.doi.org/10.1002/fut.3990130809

Fama, E. (1970). Efficient capital markets: A review of theory and empirical work. Journal of Finance, 25, 383-417. http://dx.doi.org/10.2307/2325486

French, K. (1980). Stock returns and weekend effect. Journal of Financial Economics, 8, 55-69. http://dx.doi.org/10.1016/0304-405X(80)90021-5

Fields, M. (1934). Security prices and stock exchange holidays in relation to short selling. Journal of Business, 7 , 
328-338. http://dx.doi.org/10.1086/232387

Froot, K., \& Thaler, R. (1990). Anomalies: Foreign exchange. Journal of Economic Perspectives, 4, 179-192. http://dx.doi.org/10.1257/jep.4.3.179

Garcia, P., Hudson, M., \& Waller, M. (1988). The pricing efficiency of agricultural futures markets: An analysis of previous research result. Southern Journal of Agricultural Economics, 20, 119-130.

Gibbons, M., \& Hess, P. (1981). Day of the week effects and asset returns. Journal of Business, 54, 579-596. http://dx.doi.org/10.1086/296147

Gordon, J. (1985). The distribution of daily changes in commodity futures prices. Technical Bulletin, 1702. ERS USDA.

Górska, A., \& Krawiec, M. (2013). Badania efektywności informacyjnej w formie słabiej na rynku metali szlachetnych. Zeszyty Naukowe Uniwersytetu Szczecińskiego, 768, 143-156.

Gu, A. (2003). The declining January effect: Evidence from U.S. equity markets. Quarterly Review of Economics and Finance, 43, 395-404. http://dx.doi.org/10.1016/S1062-9769(02)00160-6

Gu, A., \& Simon J. (2003). Declining January effect: Experience in the United Kingdom. American Business Review, 21, 117-121.

Haug, M., \& Hirschey, M. (2006). The January effect. Financial, Analysts Journal, 65, 78-88. http://dx.doi.org/10.2469/faj.v62.n5.4284

Helms, B., Kaen, F., \& Roseman, R. (1984). Memory in commodity futures contracts. Journal of Futures Markets, 4, 559-568. http://dx.doi.org/10.1002/fut.3990040408

Hirshleifer, D. (2001). Investor psychology and asset pricing. Journal of Finance, 56, 1533-1598. http://dx.doi.org/10.1111/0022-1082.00379

Hunt, B. (1974). Short run price cycles in the Sydney wool futures market. Australian Journal of Agricultural Economics, 18, 133-143. http://dx.doi.org/10.1111/j.1467-8489.1974.tb00133.x

Jaffe, J., \& Westerfield, R. (1985). The week-end effect in common stock returns: The international evidence. Journal of Finance, 40, 410-428. http://dx.doi.org/10.1111/j.1540-6261.1985.tb04966.x

Jaffe, J., Westerfield, R., \& Ma, C. (1989). A twist on Monday effect in stock prices: Evidence from the US and foreign stock markets. Journal of Banking and Finance, 15, 641-650. http://dx.doi.org/10.1016/0378-4266(89)90035-6

Johnson, R., \& Soenen, L. (1997). Gold as an investment asset-perspectives from different countries. Journal of Investing, 6, 94-99. http://dx.doi.org/10.3905/joi.1997.408427

Just, R., \& Rausser, G. (1975). Commodity price forecasting with large-scale econometric models and the futures markets: A survey. American Journal of Agricultural Economics, 55, 584-593. http://dx.doi.org/10.2307/1239555

Kato, K., Schwarz, S., \& Ziemba, W. (1990). Day of the weekend effects in Japanese stocks. Japanese Capital Markets. Ballinger, New York.

Keim, D. (1983). Size-related anomalies and stock return seasonality: Further empirical evidence. Journal of Financial Economics, 12, 13-32. http://dx.doi.org/10.1016/0304-405X(83)90025-9

Keim, D., \& Stambaugh, F. (1984). A further Investigation of weekend effects in stock returns. Journal of Finance, 39, 819-840. http://dx.doi.org/10.1111/j.1540-6261.1984.tb03675.x

Kellard, N., Newbold, P., Rayner, T., \& Ennew, C. (1999). The relative efficiency of commodity futures markets. $\begin{array}{llllll}\text { Journal of } & \text { Futures } & \text { Markets, } & 19, & 43-432 .\end{array}$ http://dx.doi.org/10.1002/(SICI)1096-9934(199906)19:4\%3C413::AID-FUT2\%3E3.0.CO;2-F

Keong, L., Yat, D., \& Ling, C. (2010). Month-of-the-year effects in Asian countries: A 20-year study (1990-2009). African Journal of Business Management, 7, 1351-1362.

Kim, C., \& Park, J. (1994). Holiday effects and stock returns: Further evidence. Journal of Financial and Quantitative Analysis, 29, 145-157. http://dx.doi.org/10.2307/2331196

Kim, H., Oh, G., \& Kim, S. (2011). Multifractal analysis of Korean agricultural market. Physica A, 390, 4286-4292. http://dx.doi.org/10.1016/j.physa.2011.06.046

Kim, M., Kim, J., Jo, Y., \& Kim, S. (2011). Dependence structure of the commodity and stock markets, and 
relevant multi-spread strategy. Physica A, 390, 3842-3854. http://dx.doi.org/10.1016/j.physa.2011.06.037

Kofi, T. (1972). A framework for comparing the efficiency of the futures markets. American Journal of Agricultural Economics, 55, 584-593. http://dx.doi.org/10.2307/1238343

Kramer, W. (1996). Stochastic properties of German stock returns. Empirical Economics, 21, 281-306. http://dx.doi.org/10.1007/BF01175974

Kristoufek, L., \& Vosvrda, M. (2013). Commodity futures and market efficiency. Energy Economics, 42, 50-57. http://dx.doi.org/10.1016/j.eneco.2013.12.001

Labys, W., \& Granger, C. (1970). Speculation, hedging and commodity price forecasting. Lexington MA: Health Lexington Books.

Lakonishok, J., \& Maberly, E. (1990). The weekend effect: Trading patterns of individual and institutional investors. Journal of Finance, 45, 231-243. http://dx.doi.org/10.2307/2328818

Lakonishok, J., \& Levi, M. (1982). Weekend effect on stock returns: A note. Journal of Finance, 37, 883-889. http://dx.doi.org/10.1111/j.1540-6261.1990.tb05089.x

Lakonishok, J., \& Shmidt, S. (1988). Are seasonal anomalies real. A ninety-year perspective. Review of Financial Studies, 1, 403-425. http://dx.doi.org/10.1016/0304-405X(84)90008-4

Larson, A. (1960). Measurement of a random process in future prices. Food Research Institute Studies, 1, 313-324.

Latif, M., Arshad, S., Fatima, M., \& Rarooq, S. (2011). Market efficiency, market anomalies, causes: Evidences and some behavioral aspects of market anomalies. Research Journal of Finance and Accounting, 2, 1-14.

Leath, M., \& Garcia, P. (1983).The efficiency of the corn futures markets in establishing forward prices. North Central Journal of Agricultural Economics, 5, 91-101. http://dx.doi.org/10.2307/1349144

Lee, K., Hsu, C., \& Ke, M. (2013). Testing the monthly effect of agricultural futures markets with stochastic dominance. International Review of Accounting, Banking and Finance, 5, 35-60.

Lokare, S. (2007). Commodity derivatives and price risk management: An empirical anecdote from India. Reserve Bank of India Occasional Papers, 28.

Marquering, W., Nisser, J., \& Valla, T. (2006). Disappearing anomalies: A dynamic analysis of the persistence ofanomalies. Applied Financial Economics, 16, 291-302. http://dx.doi.org/10.1080/09603100500400361

Martell, T., \& Helms, B. (1978). A re-examination of price changes in the commodity futures markets. International Futures Trading Seminar, 5. Chicago Board of Trade.

Martell, T., \& Philipatos, G. (1974). Adoption information and dependence in commodity markets. Journal of Finance, 29, 493-498. http://dx.doi.org/10.2307/2978818

Mckenzie, A., \& Holt, M. (1998). Market efficiency in agricultural futures markets. American Agricultural Economics Association Annual Meeting, Salt Lake City.

Mckenzie, A., \& Holt, M. (2002). Market efficiency in agricultural futures markets. Applied Economics, 34, 1519-1532. http://dx.doi.org/10.1080/00036840110102761

Mills, T., \& Coutts, J. (1995). Calendar effects in the London Stock Exchange FTSE indices. European Journal of Finance, 1, 79-93. http://dx.doi.org/10.1080/13518479500000010

Otto, S. (2011). A speculative efficiency analysis of the London Metal Exchange in a multi-contract framework. International Journal of Economics and Finance, 3, 3-16. http://dx.doi.org/10.5539/ijef.v3n1p3

Osinska, M. (2006). Ekonometria finansowa. Warszawa: PWE.

Ovararin, K., \& Meade, N. (2010). Mean reversion and seasonality in GARCH of Agricultural commodities. International Conference on Applied Economics, ICOAE 2010, pp. 573-581.

Peiro, E. (1994). Daily seasonality in stock returns: Further international evidence. Economics Letters, 45, 227-232. http://dx.doi.org/10.1016/0165-1765(94)90140-6

Rausser, G., \& Carter, C. (1983). Futures market efficiency in the soybean complex. Review of Economics and Statistics, 65, 469-478. http://dx.doi.org/10.1016/0304-405X(76)90028-3

Roll, R. (1984). Orange juice and weather. American Economic Review, 74, 861-880.

Roll, R. (1988). R². Journal of Finance, 44, 1-17. http://dx.doi.org/10.1111/j.1540-6261.1988.tb04591.x 
Ross, S. (2005). Neoclassical finance. Princeton, NJ: Princeton University Press.

Sabuhoro, J., \& Larue, B. (1997). The market efficiency hypothesis: The case of coffee and cocoa futures. Agricultural Economics, 16, 171-184. http://dx.doi.org/10.1016/S0169-5150(97)00003-0

Sahoo, P., \& Kumar, R. (2009). Efficiency and futures trading-Price nexus in Indian commodity futures markets. Global Business Review, 10, 187-201. http://dx.doi.org/10.1177/097215090901000204

Schwert, W. (2002). Anomalies and market efficiency. Working Paper no. FR 02-13, Simon School of Business. http://dx.doi.org/10.2139/ssrn.338080

Sehgal, S., Rajput, N., \& Dua, R. (2012). Price discovery in Indian agricultural commodity markets. International Journal of Accounting and Financial Reporting, 2, 34-54. http://dx.doi.org/10.5296/ijafr.v2i2.2224

Seow, K., \& Wong, N. (1998). The diminishing calendar anomalies in the stock exchange of Singapore. Applied Financial Economics, 8, 119-125. http://dx.doi.org/10.1080/096031098333096

Simson, E. (1988). Stock market anomalies. Cambridge: Cambridge University Press.

Smidt, S. (1965). A test of the serial independence of price changes in soybean futures. Food Research Institute Studies, 5, 117-136.

Solnik, B., \& Bosquet, L. (1990). Day-of-the-week effect on the Paris Bourse. Journal of Banking and Finance, 14, 461-468. http://dx.doi.org/10.1016/0378-4266(90)90059-B

Spriggs, J. (1981). Forecasting of Indiana monthly farm prices using Univariate Box-Jenkins analysis and corn futures prices. North Central Journal of Agricultural Economy, 3, 81-87. http://dx.doi.org/10.2307/1349412

Sutheebanjard, P., \& Premchaiswadi, W. (2010). Analysis of calendar effects: Day-of-the-week effect on the Stock Exchange of Thailand (SET). International Journal of Trade, Economics and Finance, 1, 2010-2023. http://dx.doi.org/10.7763/IJTEF.2010.V1.11

Stevenson, R., \& Bear, R. (1970). Commodity futures trends or random walk. Journal of Finances, 25, 65-81. http://dx.doi.org/10.1111/j.1540-6261.1970.tb00414.x

Szyszka, A. (2007). Wycena papierów wartościowych na rynku kapitałowym w świetle finansów behawioralnych. Poznań: Wydawnictwo Akademii Ekonomicznej w Poznaniu.

Theobald, M., \& Price, V. (1984). Seasonality estimation in thin markets. Journal of Finance, 39, 377-392. http://dx.doi.org/10.1111/j.1540-6261.1984.tb02315.x

Tomek, W., \& Gray, R. (1970). Temporal relationship among prices on commodity futures markets: Their allocative and stabilizing role. American Journal of Agricultural Economics, 52, 372-380. http://dx.doi.org/10.2307/1237388

Wang, H., \& Ke, B. (2005). Efficiency tests of agricultural commodity futures markets in China. Australian Journal of Agricultural and Resource Economics, 49, 125-141. http://dx.doi.org/10.1111/j.1467-8489.2005.00283.x

Zunino, L., Tabak, M., Serinaldi, F., Zanin, M., Perez, G., \& Rosso, O. (2011). Commodity predictability analysis with a permutation information theory approach. Physica A, 390, 876-890. http://dx.doi.org/10.1016/j.physa.2010.11.020

\section{Copyrights}

Copyright for this article is retained by the author(s), with first publication rights granted to the journal.

This is an open-access article distributed under the terms and conditions of the Creative Commons Attribution license (http://creativecommons.org/licenses/by/3.0/). 